\title{
Effect of Chemically Disinfected Wheat Straw on the Growth and Yield of Pleurotus Ostreatus Mushroom
}

\author{
Kanij Mohoua Roksana \\ Dept. of Biochemistry, Faculty of Agriculture, Sher-e-Bangla Agricultural University \\ Sher-e-Bangla Nagar, Dhaka-1207, Bangladesh.
}

Dr. Kamal Uddin Ahmed

Dept. of Biochemistry, Faculty of Agriculture, Sher-e-Bangla Agricultural University

Sher-e-Bangla Nagar, Dhaka-1207. Bangladesh.

\begin{abstract}
Md. Nashir Uddin (Corresponding author)
Dept. of Biochemistry and Microbiology, School of Life Sciences, North South University

Plot-15, Block-B, Bashundhara R/A, Dhaka-1229. Bangladesh

E-mail: nasir.uddin05@northsouth.edu
\end{abstract}

Received: January 16, 2018

Accepted: January 30, 2018

doi:10.5296/jas.v6i1.12487

URL: https://doi.org/10.5296/jas.v6i1.12487

\begin{abstract}
We investigated the effect of chemically disinfected wheat straw on the growth and yield of oyster mushroom (Pleurotus ostreatus). Various levels of treatments combined with different time (12, 18 and 24 hours) and dose of Formalin (250, 500 and 750ppm) and Bavistin (75ppm) were used, and the results were compared with the control. Compared to the control, almost all the treatments showed increased values, and among them significantly higher mycelium running rate, the lowest time from stimulation to primordial initiation and to harvest, number of primordial per packet, number of fruiting body per packet were found in treatment consists of 750ppm of Formalin with 75ppm of Bavistin for 18 hours. Length and diameter of the stipe, diameter and thickness of pileus, biological yield, economic yield, dry yield and biological efficiency were also significantly increased in this treatment. Wheat straw treated with 500ppm of Formalin with $75 \mathrm{ppm}$ of Bavistin for 18 hours performed best in terms of per cent protein and nitrogen content. However, weight of individual fruiting body
\end{abstract}


was significantly higher when treated with 250ppm Formalin with 75ppm of Bavistin for 24 hours.

As the sterilization of wheat straw using 750ppm of formalin with $75 \mathrm{ppm}$ of Bavistin for 18 hours could control pathogens and gave increased yield, this treatment might be useful as an economically effective treatment for the highest yield of oyster mushroom.

Keywords: Pleurotus ostreatus, Chemical disinfection, Fungicide, Formalin, Bavistin, Substrate, Wheat straw

\section{Introduction}

Mushrooms are large reproductive structure (fruiting body) of edible fungi, and oyster mushroom, Pleurotus ostreatus, is most suited to the climatic condition of Bangladesh and the tropical areas as well. It is a good source of protein, vitamins and minerals (Khan et al., 1981), and at fresh harvest it contains about $85-95 \%$ water, $3 \%$ protein, $4 \%$ carbohydrates, $0.1 \%$ fats and $1 \%$ minerals and vitamins (Tewari, 1986). Mushroom reduces the diabetes (Anderson and Ward, 1979), serum cholesterol in human bodies that helps in controlling hypertension (Suzuki and Oshima, 1979) on regular feeding. It is a valuable healthy food with low calories, higher vegetable proteins, zinc, chitin, fiber, vitamins and minerals (Alam and Saboohi, 2001). Edible mushrooms are recommended by the FAO as food, to meet protein requirement of developing countries, the large proportion of which depends mainly on cereals (World Bank, 2004).

Oyster mushroom contains $19-35 \%$ protein on dry weight basis as compared to $7.3 \%$ in rice $13.2 \%$ in wheat and $25.2 \%$ in milk (Chang \& Miles, 1988). It contains $4.0 \%$ fat having good quantity of unsaturated fatty acids which are essential in our diet (Holman, 1976). It is rich in essential minerals and trace elements (Chandha and Sharma, 1995) and the amount of niacin, pantothenic acid and biotin are of appreciable level (Subramanian, 1986). The cultivation of oyster mushrooms has become an attractive economic alternative due to its high demand and market value (Chang, 2006).

Because of their high saprophyte characteristics, most Pleurotus species grows on lingo-cellulose materials such as rotten wood, wood chips, and agricultural postharvest residues (Straatsma et al., 2000; Stamets, 2000). Recycling of these unfavorable materials through mushroom culture can increase agricultural efficiency and enhance the degradation processes of lingo-cellulose sources (Obodai et al., 2003). Selection of suitable substrate is necessary to get good growth as they affect the growth, yield, quality and nutritional values (Sarker et al., 2007a). Wheat straw was used successfully as substrate and gave good yields of oyster mushroom (Hoa et al. 2015).

However, the parameters including substrate source, substrate quality, spawn, strain, compost, and complement affects the growth and performance for high yield of oyster mushroom (Royes et al. 2004; Jafarpour et al., 2010). A wide range of disease can cause serious problems in mushroom cultivation, and condition in Bangladesh such as high humidity and warm temperature are favored by many pathogens. Disinfect or pasteurize the substrate is one of the important practice for this disease management (Mushroom growers handbook, 2004). 
Chemical disinfection is recommended as it is cheaper than the other sterilization methods such as steam sterilization (Afyon, 1988). And, no residual effects found in mushroom after chemical sterilization. Previously, chemical treatment with $1 \%$ formaldehyde together with $2.0 \%$ copper sulphate gave satisfactory yields, and but maximum control of green mould in oyster mushroom was obtained when treated with thiabendazole at $5 \mathrm{~g} / \mathrm{m}^{2}$ to the substrate before pasteurization (Jhune et al., 1990). The effects of these fungicides and their optimum concentration were not clear. To overcome this issue, it was necessary to find suitable chemical disinfectant that was easily available with low cost and more yielding with their optimum concentration to control different mycoflora associated with oyster mushroom to increase its yield.

The objectives of this study were to find out suitable time (hours) and dose (concentration) of two easily available fungicide, Formalin and Bavistin, for the sterilization of wheat straw, and their effects on the growth and yield of oyster mushroom. The findingss will be useful for the better cultivation and higher yield of Pleurotus ostreatus

\section{Materials \& Method}

The experiment was carried out at the Mushroom Culture House of the Biochemistry laboratory in the Department of Biochemistry at Sher-e-Bangla Agricultural University in Dhaka, and the National Mushroom Development and Extension Center (NAMDEC) laboratory in Savar during the period from January to June, 2013. Fruiting body of oyster mushroom was collected from NAMDEC, wheat straw from the local bazaar, and the chemicals were collected from fertilizer shop respectively.

Treatments were composed of different combination of time and dose of Formalin \& Bavistin and a total of 10 set of treatments were used in this study including the control. The compositions of the treatments $(\mathrm{T})$ are as follows:

T1 (Control): 0ppm of Formalin and 0 ppm of Bavistin for 24 hours; T2: 250ppm Formlin and 75ppm of Bavistin for 12 hours; T3: 500ppm Formalin and 75ppm of Bavistin for 12 hours; T4: 750ppm Formalin and 75ppm of Bavistin for 12 hours; T5: 250ppm Formlin and 75ppm of Bavistin for 18 hours; T6: 500ppm Formalin and 75ppm of Bavistin for 18 hours;

T7: 750ppm Formalin and 75ppm of Bavistin for 18 hours; T8: 250ppm Formlin and 75ppm of Bavistin for 24 hours; T9: 500ppm Formalin and 75ppm of Bavistin for 24 hours; T10: 750ppm Formalin and 75ppm of Bavistin for 24 hours

\subsection{Preparation of Substrates and Sterilization}

The collected wheat straw was soaked in the water with chemicals according to the composition of treatments. After the treatment time was over, the straw was taken off and left them on perforated sacs for the removal of excess water. Then the wet straw was spreaeded in clean polythene set on the floor for sun drying, and $\mathrm{CaCO}_{3}$ at a rate of $1 \%$ on dry weight basis is mixed with the straw. 


\subsection{Inoculation and Preparation of Spawn Packets}

The $400 \mathrm{gm}$ of mixed substrates were filled into the $9 \times 12$ inches polypropylene bag with $20 \%$ mother spawn into three layers. The filled polypropylene bags were prepared by using plastic neck and plugged the neck with cotton and covered with brown paper placing rubber band to hold it tightly in place.

\subsection{Cultivation of Spawn Packet}

The moisture of the culture room was maintained $80-85 \%$ relative humidity by spraying water 3 times a day. The light around 300-500 lux and ventilation of culture house was maintained uniformly. The temperature of culture house was maintained $22^{\circ} \mathrm{C}$ to $25^{\circ} \mathrm{C}$. The first primordia appeared 2 to 4 days after scribing depending upon the type of substrate.

\subsection{Collection of produced mushrooms}

The matured fruiting body was identified by curial margin of the cap, as described by Amin (2002). Mushrooms were harvested by twisting to uproot from the base.

\subsection{Traits investigated}

\section{Mycelial growth, \% (MG):}

Mycelial growth was counted by taking the full packet as a full unit and generally the data was taken at every two days intervals.

\section{Mycelium running rate in spawn packet, cm (MRR):}

The linear length was measured at different places of packet using the average length of mycelium running for different places (L) divided by number of days $(\mathrm{N})$ following the formula proposed by Sarker, 2004):

$$
M R R=\frac{L}{N} c m / d a y
$$

\section{Days from stimulation to primordial initiation (DFSPI):}

Days required from inoculation to completion of mycelium running were recorded .Percent increase of average number of primordial using the treatment from treatment 2 to 10 over control.

\section{Number \& weight of individual fruiting body per packet (NIFPP, WIFPP):}

Number of well-developed fruiting body was recorded. Average weight of individual fruiting body was calculated by dividing the total weight of fruiting body per packet by the total number of fruiting body per packet. The overview of the experiment is shown in figure 1.

\section{Dimension (stipe and pileus) of fruiting body (DOF):}

Length of the stips (LSt) of three randomly selected fruiting bodies was measured using a slide calipers. Diameter of stipe (DSt), diameter and thickness of pileus (Dpi, TPi) were also 


\section{Macrothink}

measured.

\section{Biological yield (BY):}

Biological yield per $400 \mathrm{~g}$ packet was measured by weighing the whole cluster of fruiting body without removing the lower hard and dirty portion.

\section{Economic yield (EY):}

Economic yield per $400 \mathrm{~g}$ packet was recorded by weighing all the fruiting bodies in a packet after removing the lower hard and dirty portion.

\section{Dry yield (DY):}

The dry yield was calculated using the following formula (Sarker, 2004):

\section{Dry yield $(\mathrm{g} / 400 \mathrm{~g}$ packet $)=\frac{\text { Economic yield } \times \text { oven dry weight of sample }(\mathrm{g})}{\text { fresh weight of stinniple }}$}
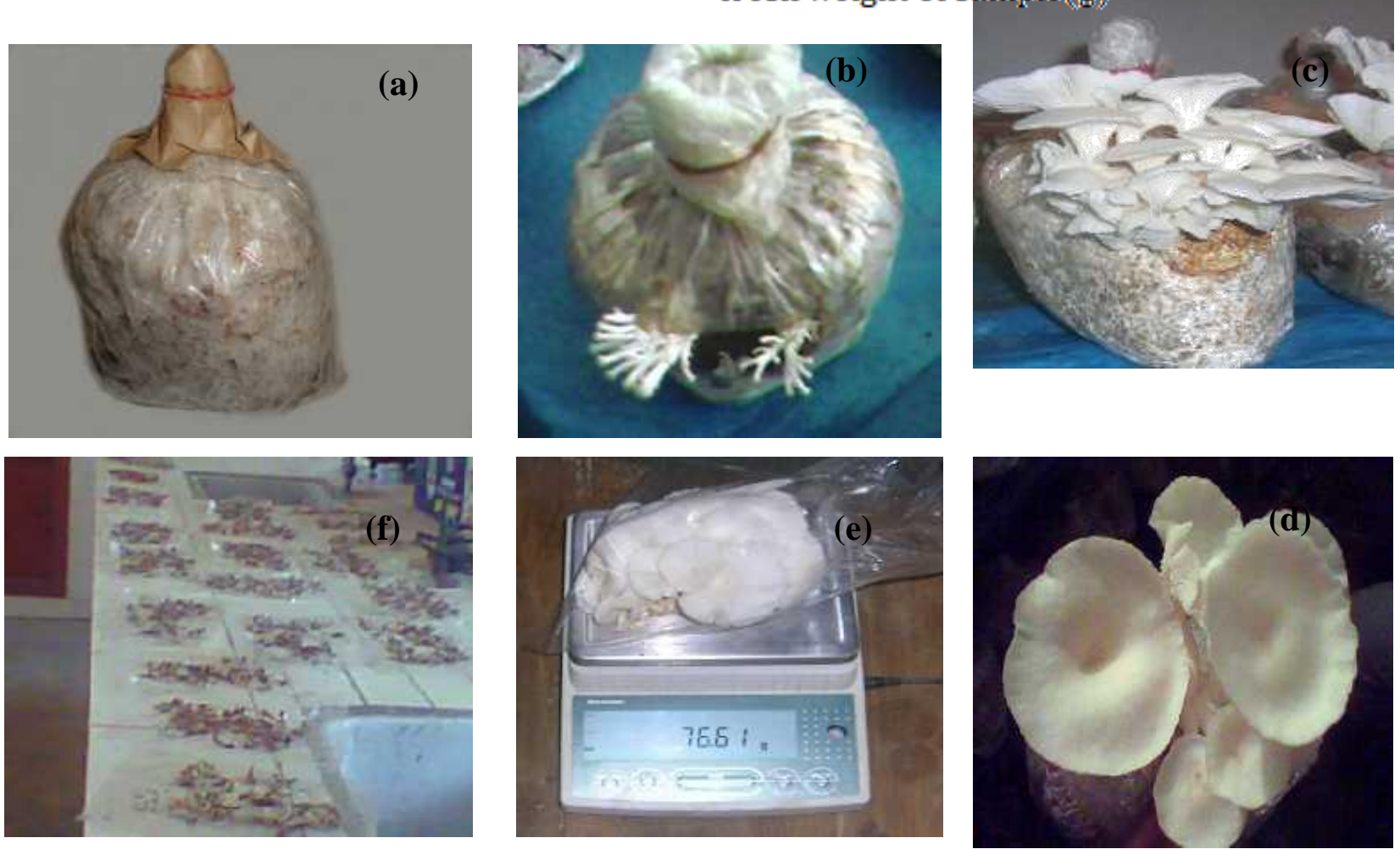

Figure 1: Representative steps of the experiments and set up (Clockwise)

a) Mycelium running in spawn packet (18 days after of inoculation); b) Pin head primordia in the spawn packet; c) Young fruiting body; d) Matured fruiting body; e) Measuring biological weight; f) Oven dried mushroom in laboratory prior to measure dry weight 
Biological efficiency $(B E)$ :

Biological efficiency was determined by the following formula:

$$
B E=\frac{\text { Total biological weight }(g)}{\text { Total dry weight of substrate used }(g)} \times 100
$$

\section{Statistical analysis of data:}

All the data collected on different parameters were statistically analyzed by following the analysis of variance (ANOVA) method and mean differences were adjusted by Duncan's Multiple Range Test (DMRT) (Gomez and Gomez, 1984) using the MSTAT-c computer package program. The mean differences among the treatments were compared by least significant difference (LSD) test at 5\% level of significance.

\section{Result \&Discussion}

\subsection{Effect on Mycelium Growth}

MRR per day for each type of substrates was measured after the mycelium colony crossed the shoulder of the packet. Results showed wide variations among the treatments and almost all the treatments had significantly higher MRR than the control (Table 1). The highest MRR was observed in $\mathrm{T}_{7}(0.79 \mathrm{~cm})$ and the lowest running rate of mycelium $(0.53 \mathrm{~cm})$ was observed in $\mathrm{T}_{1}$ (Table 1). These results corroborated with the previous reports by Jhune et al. (1990), Rai and Vijay (1992), Namdev et al. (2006), Khaliq et al. (2013), but the MRR were comparably higher in these combination of treatments in this study.

The DFSPI was varied greatly among the treatments and took significantly shorter days than the control. The lowest DFSPI was observed in the treatment $\mathrm{T}_{7}$ (6.04 days) and the highest was observed in the treatment $\mathrm{T}_{1}$ (8.57 days). These results corresponded with the previous reports published by Gupta (1989), Khan et al, (2010), Royse (2002), and Amin et al. (2007), but the time required from stimulation to primordial initiation was shorter (6.04 days) than previous reports.

\section{DFPITH}

The lowest time from primordial initiation to harvest was recorded in the treatment $\mathrm{T}_{7}(3.56$ days) and the highest time from primordial initiation to harvest was observed in the treatment $\mathrm{T}_{1}$ (4.66 days) (Table 1). These results showed the shortest DFPITH than the previous studies reported by Dhoke et al. (2001) who found that the days required for first picking varied from 11.25-12.00 and the final picking completed from 42.25 to 43.50 days depending on different substrates.

\section{NPPP}

The lowest NPPP was observed from the treatment $\mathrm{T}_{1}$ (53.33) and the highest was found in the treatment $\mathrm{T}_{7}$ (82.67) (Table 1). The treatment $\mathrm{T}_{5}$ and $\mathrm{T}_{6}$ also showed good performance but not up to the $\mathrm{T}_{7}$. The result of this study corroborates with the study of previous reports 
by Amin (2002). Dey (2006) found that the number of primordia of oyster mushroom significantly varied with the variation of substrates used.

\section{NIFPP}

The highest NIFPP was observed in the treatment $\mathrm{T}_{7}$ (64.33) and the lowest was in the treatment $T_{1}$ (33.33) (Table 1). Previously, Yoshida et al. (1993) also reported that the number of fruiting bodies was lower when only wheat straw was used, but increased when the substrates was mixed with wheat bran.

Table 1. Effect of chemical treated wheat straw on mycelium growth and yield

Contributing Characters of oyster mushroom

\begin{tabular}{|c|c|c|c|c|c|c|}
\hline Treatments & $\begin{array}{l}\text { MRR } \\
(\mathrm{cm})\end{array}$ & $\begin{array}{l}\text { DFSPI } \\
\text { (days) }\end{array}$ & $\begin{array}{l}\text { DFPITH } \\
\text { (days) }\end{array}$ & NPPP & NIFPP & $\begin{array}{l}\text { WIFPP } \\
(\mathrm{g})\end{array}$ \\
\hline $\mathrm{T}_{1}$ & $0.53 \mathrm{~h}$ & $8.57 \mathrm{a}$ & $4.66 \mathrm{a}$ & $53.33 \mathrm{f}$ & $33.33 \mathrm{f}$ & $2.23 \mathrm{e}$ \\
\hline $\mathrm{T} 2$ & $0.61 \mathrm{~g}$ & $7.02 \mathrm{~b}$ & $3.91 \mathrm{~b}$ & $58.67 \mathrm{e}$ & $49.00 \mathrm{de}$ & $2.71 \mathrm{~d}$ \\
\hline $\mathrm{T} 3$ & $0.65 \mathrm{f}$ & $6.73 \mathrm{c}$ & $3.85 \mathrm{c}$ & $65.00 \mathrm{~d}$ & $46.33 \mathrm{e}$ & $3.05 \mathrm{abc}$ \\
\hline $\mathrm{T}_{4}$ & $0.69 \mathrm{e}$ & $6.67 \mathrm{~cd}$ & 3.75 ef & $70.67 \mathrm{c}$ & $51.33 \mathrm{~cd}$ & $2.87 \mathrm{bcd}$ \\
\hline $\mathrm{T} 5$ & $0.71 \mathrm{~cd}$ & $6.57 \mathrm{de}$ & $3.71 \mathrm{fg}$ & $72.67 \mathrm{bc}$ & $54.00 \mathrm{bc}$ & $2.90 \mathrm{abcd}$ \\
\hline T6 & $0.75 \mathrm{~b}$ & $6.45 \mathrm{e}$ & $3.66 \mathrm{~g}$ & $75.67 \mathrm{bc}$ & $56.33 \mathrm{~b}$ & $2.97 \mathrm{abcd}$ \\
\hline $\mathrm{T} 7$ & $0.79 \mathrm{a}$ & $6.04 \mathrm{f}$ & $3.56 \mathrm{~h}$ & $82.67 \mathrm{a}$ & $64.33 \mathrm{a}$ & $2.79 \mathrm{~cd}$ \\
\hline $\mathrm{T} 8$ & $0.73 \mathrm{c}$ & $6.49 \mathrm{e}$ & $3.70 \mathrm{fg}$ & $76.00 \mathrm{~b}$ & $51.33 \mathrm{~cd}$ & $3.18 \mathrm{a}$ \\
\hline T9 & $0.70 \mathrm{de}$ & $6.70 \mathrm{~cd}$ & $3.78 \mathrm{de}$ & $72.33 \mathrm{bc}$ & $52.67 \mathrm{bcd}$ & $3.08 \mathrm{ab}$ \\
\hline $\mathrm{T}_{10}$ & $0.72 \mathrm{~cd}$ & $6.75 \mathrm{c}$ & $3.81 \mathrm{~cd}$ & $74.33 \mathrm{bc}$ & $55.67 \mathrm{bc}$ & $3.02 \mathrm{abc}$ \\
\hline LSD (0.05) & 0.01715 & 0.1329 & 0.05425 & 5.273 & 4.860 & 0.2870 \\
\hline $\mathrm{CV}(\%)$ & 2.58 & 1.13 & 0.72 & 4.38 & 5.51 & 5.80 \\
\hline
\end{tabular}

In a column the figures having a common letter(s) do not differ significantly at $5 \%$ level.

( MRR, Mycelial running rate; DFSPI, Days from stimulation to primordial initiation; DFPITH, Days from primordial initiation to harvest; NPPP, Number of primordial per packet; NIFPP, Number of individual fruiting body per packet; WIFPP, Weight of individual fruiting body per packet) 


\section{WIFPP}

The highest WIFPP was observed in the treatment $\mathrm{T}_{8}$ (3.18) and the lowest was found in the treatment $\mathrm{T}_{1}$ (2.23). The other treatments differed significantly in terms of average weight of individual fruiting body (Table 1). Sarker et al. (2007a) reported the individual weight of fruiting body ranges from 1.33-1.59 $\mathrm{g}$, and in this study, we found that the weight of individual fruiting body ranged from 2.23 to $3.18 \mathrm{~g}$. This was might be due to the effects of disinfection through chemical treatments.

\section{DOF}

The highest average length of stipe was observed in the treatment $\mathrm{T}_{7}(2.83 \mathrm{~cm})$ and the lowest average length of stipe was in the treatment $\mathrm{T}_{1}(2.30 \mathrm{~cm})$. The highest diameter of stipe was observed in the treatment $\mathrm{T}_{7}(0.88 \mathrm{~cm})$ and the lowest average diameter of stipe was in the treatment $\mathrm{T}_{1}(0.67 \mathrm{~cm})$. The highest diameter of pileus was observed in the treatment $\mathrm{T}_{7}(5.71$ $\mathrm{cm})$ and the lowest average diameter of pileus was in the treatment $\mathrm{T}_{1}(3.50 \mathrm{~cm})$. The highest average thickness of pileus was observed in the treatment $T_{7}(0.85 \mathrm{~cm})$ and the lowest average thickness of pileus was in the treatment $T_{1}(0.66 \mathrm{~cm})$. (Table 2). Ahmed (1998) found that lower diameter of pileus produced the lowest yield and concluded that the diameter of pileus increased the quality and yield of mushroom and highest dry yield from mango sawdust. Habib (2005) found that the diameter of pileus ranged from $4.85 \mathrm{~cm}$ to $8.95 \mathrm{~cm}$ and thickness of the pileus ranged from $0.45 \mathrm{~cm}$ to $0.70 \mathrm{~cm}$ due to different substrates. He also mentioned that the length of stipe of oyster mushroom on different substrates varied from $1.93 \mathrm{~cm}$ to $2.97 \mathrm{~cm}$ and the diameter ranged from $0.74 \mathrm{~cm}$ to $1.05 \mathrm{~cm}$.

\subsection{Effect On Yield}

\section{BY}

The highest biological yield was recorded from the treatment $\mathrm{T}_{7}(185.8 \mathrm{~g})$ and the lowest biological yield was recorded from $\mathrm{T}_{1}(78.09 \mathrm{~g})$. The rest of the treatments differed significant as compared to control (Table 3). Chowdhury et al. (1998) examined and reported the highest yield of oyster mushroom when added $5 \%$ additional supplements to the

Table 2. Effect of chemical treated wheat straw on the dimension of fruiting body of oyster mushroom

\begin{tabular}{ccccc}
\hline Treatments & $\begin{array}{c}\text { LSt } \\
(\mathrm{cm})\end{array}$ & $\begin{array}{c}\text { DSt } \\
(\mathrm{cm})\end{array}$ & $\begin{array}{c}\text { DPi } \\
(\mathrm{cm})\end{array}$ & $\begin{array}{c}\text { TPi } \\
(\mathrm{cm})\end{array}$ \\
\hline $\mathrm{T}_{1}$ & $2.30 \mathrm{~h}$ & $0.67 \mathrm{f}$ & $3.50 \mathrm{i}$ & $0.66 \mathrm{f}$ \\
$\mathrm{T}_{2}$ & $2.53 \mathrm{~g}$ & $0.71 \mathrm{e}$ & $4.44 \mathrm{~h}$ & $0.713 \mathrm{e}$ \\
$\mathrm{T} 3$ & $2.58 \mathrm{f}$ & $0.72 \mathrm{de}$ & $4.52 \mathrm{~g}$ & $0.74 \mathrm{~d}$ \\
$\mathrm{~T} 4$ & $2.61 \mathrm{e}$ & $0.73 \mathrm{~d}$ & $4.64 \mathrm{f}$ & $0.76 \mathrm{~cd}$ \\
$\mathrm{~T} 5$ & $2.66 \mathrm{~d}$ & $0.76 \mathrm{c}$ & $5.07 \mathrm{e}$ & $0.77 \mathrm{c}$
\end{tabular}




\begin{tabular}{ccccc} 
T6 & $2.78 \mathrm{~b}$ & $0.80 \mathrm{~b}$ & $5.61 \mathrm{~b}$ & $0.80 \mathrm{~b}$ \\
$\mathrm{~T} 7$ & $2.83 \mathrm{a}$ & $0.88 \mathrm{a}$ & $5.71 \mathrm{a}$ & $0.85 \mathrm{a}$ \\
$\mathrm{T} 8$ & $2.73 \mathrm{c}$ & $0.73 \mathrm{~d}$ & $5.20 \mathrm{~d}$ & $0.76 \mathrm{~cd}$ \\
$\mathrm{~T} 9$ & $2.73 \mathrm{c}$ & $0.74 \mathrm{~cd}$ & $5.23 \mathrm{~d}$ & $0.76 \mathrm{~cd}$ \\
$\mathrm{~T} 10$ & $2.74 \mathrm{c}$ & $0.75 \mathrm{c}$ & $5.42 \mathrm{c}$ & $0.79 \mathrm{~b}$ \\
\hline $\mathrm{LSD}(0.05)$ & 0.01715 & 0.01715 & 0.05425 & 0.01715 \\
$\mathrm{CV}(\%)$ & 0.69 & 2.25 & 0.64 & 1.49 \\
\hline
\end{tabular}

In a column the figures having a common letter(s) do not differ significantly at $5 \%$ level.

(LSt, Length of stipe; DSt, Diameter of stipe; DPi,Diameter of pileus; TPi, Thickness of pileus)

substrates. Dhoke et al. (2001) found significant effect of different agro-wastes on yield of oyster mushroom.

\section{EY}

The highest economic yield was recorded from the treatment T7 (179.0 g) and the lowest economic yield was recorded from T1 $(73.86 \mathrm{~g})$. The economic yield of the rest of the treatments differed statistically compared to control (Table 3). Amin et al. (2007) found that the trend of economic yield corresponded with different supplements at different level. Conducting yield values were higher than previous.

Table 3. Effect of chemical treated wheat straw on the yield and biological efficiency of oyster mushroom

\begin{tabular}{cllll}
\hline Treatments & BY & EY & DY & BE \\
& $(\mathrm{gm})$ & $(\mathrm{gm})$ & $(\mathrm{gm})$ & $(\%)$ \\
\hline $\mathrm{T} 1$ & $78.09 \mathrm{i}$ & $73.86 \mathrm{~h}$ & $7.740 \mathrm{~h}$ & $43.44 \mathrm{~h}$ \\
$\mathrm{~T} 2$ & $138.7 \mathrm{~h}$ & $132.5 \mathrm{~g}$ & $13.58 \mathrm{~g}$ & $77.96 \mathrm{~g}$ \\
$\mathrm{~T} 3$ & $145.8 \mathrm{~g}$ & $140.7 \mathrm{f}$ & $14.61 \mathrm{f}$ & $82.75 \mathrm{f}$ \\
$\mathrm{T}_{4}$ & $152.7 \mathrm{f}$ & $147.1 \mathrm{e}$ & $15.34 \mathrm{e}$ & $86.50 \mathrm{e}$ \\
$\mathrm{T}_{5}$ & $160.9 \mathrm{e}$ & $155.9 \mathrm{~d}$ & $15.87 \mathrm{~d}$ & $91.73 \mathrm{~d}$ \\
$\mathrm{~T} 6$ & $172.8 \mathrm{c}$ & $167.2 \mathrm{~b}$ & $17.22 \mathrm{~b}$ & $98.34 \mathrm{~b}$ \\
$\mathrm{~T}_{7}$ & $185.8 \mathrm{a}$ & $179.0 \mathrm{a}$ & $18.48 \mathrm{a}$ & $105.3 \mathrm{a}$ \\
$\mathrm{T} 8$ & $168.8 \mathrm{~d}$ & $163.0 \mathrm{c}$ & $16.61 \mathrm{c}$ & $95.90 \mathrm{c}$ \\
$\mathrm{T}_{9}$ & $167.5 \mathrm{~d}$ & $162.3 \mathrm{c}$ & $16.46 \mathrm{c}$ & $95.44 \mathrm{c}$
\end{tabular}




\section{MInstitute Macrothink}

\begin{tabular}{ccccc}
$\mathrm{T} 10$ & $174.8 \mathrm{~b}$ & $167.9 \mathrm{~b}$ & $17.27 \mathrm{~b}$ & $98.78 \mathrm{~b}$ \\
\hline $\mathrm{LSD}(0.05)$ & $\cdot 1.538$ & $\cdot 1.921$ & $\cdot 0.2870$ & $\cdot 1.130$ \\
$\mathrm{CV}(\%)$ & 0.58 & 0.75 & 1.10 & 0.75 \\
\hline
\end{tabular}

In a column the figures having a common letter(s) do not differ significantly at $5 \%$ level.

(BY, Biological yield; EY, Economical yield; DY, Dried yield; BE, Biological efficiency)

\section{DY}

The maximum dry yield of mushroom was recorded from the treatment $\mathrm{T}_{7}(18.48 \mathrm{~g})$. The lowest dry yield was recorded from $\mathrm{T}_{1}(7.74 \mathrm{~g})$. The other treatments differed statistically compared to control (Table 3). This result corroborated with the previous studies (Sarker et al.,2007a; Dey,2006; Domondon and Pope,2000; Shukla and Bishwas,2000; Rab,1999). However, Rab (1999) found after chemical analysis that the methods did not significantly affect the dry matter and composition of P.sajor-caju.

\section{BE}

The highest biological efficiency, $105.3 \%$, was observed in the treatment $\mathrm{T}_{7}$ and the lowest biological efficiency, $43.44 \%$, was observed from $\mathrm{T}_{1}$. The rest of the treatments varied significantly over control (Table 3).Present findings showed the similar tendencies with the previous reports (Biswas et al., 1997; Kalita et al., 1997; Shukla and Bishwas, 2000). Biswas et al.(1997) and found that supplementation of substrate promoted biological efficiency (125.75\%). Kalita et al. (1997) observed biological efficiency for different substrates ranged from 35.2 to $60.9 \%$. The combination of treatment with the different concentration of Bavistin and Formalin increased the BE than other previous combination.

\section{Conclusions}

Oyster mushroom is an important constituent of the diet because of their high energy value and percent $(\%)$ of protein. To increase its production, suitable sterilization technique is important. Chemical sterilization is cheaper than other current technique. Based on our results, it can be concluded that Wheat straw treated with $750 \mathrm{ppm}$ of Formalin with $75 \mathrm{ppm}$ of Bavistin for 18 hours is found to be contributed significantly in yield and yield contributing characters and provided the best results with the highest yield and biological efficiency.

This treatment gave the best results and can be recommended as an economically effective for oyster mushroom cultivation. Besides, the treatment combined with 500ppm Formalin and 75ppm Bavistin for 18 hours may be a fair option for protein content. Further studies using physiological and chemical approaches are necessary to justify the present results. 


\section{References}

Ahmed, S. (1998). Performance of differerent substrates on the growth and yield of Oyster mushroom (Pleurotus sajor-caju (Fr.) Sing). M.S. thesis, Institute of Postgraduate Studies in Agriculture, Salna. Gazipur.

Alam, S. M. \& Saboohi, R. (2001). Importance of mushroom. Available at http://www.mushroomworld.com

Amin, S.M.R. (2002). Performance of different Oyster mushroom (Pleurotus spp.) varieties. M.S.Thesis. Bangabundhu Sheikh Mujibur Rahman Agricultural University, Salna, Gazipur.

Amin, S.M.R., Sarker, N. C., Khair, A. \& Alam, N. (2007). Detection of Novel Supplements on Paddy Straw Substrates on Oyster Mushroom Cultivation. Bangladesh Journal of Mushroom. 1(2): 33-37. http://www.namdec.gov.bd/images/efa/1_2_5.pdf

Anderson, J.W. and Ward, K. (1979) High Carbohydrate high fiber diets for insulin-treated man with diabetes mellitus. American Journal of Clinical Nutritrion. 32: 2313.

https://www.ncbi.nlm.nih.gov/pubmed/495550

Biswas, M.K., Shukla, C.S. and Kumar, S.M. (1997). Method for increasing biological efficiency of Oyster mushroom (Pleurotus florida) in Madhya Pradesh. Advanced Plant Science. 10 (1): 69-74. https://geoscience.net/research/002/893/002893863.php

Chandha, K.L. and Sharma, S.R. (1995). Advances in Horticulture. Mushroom, Malhotra Publication house, New Delhi.13, pp. 649.

Chang, S.T. (2006). Development of the culinary-medicinal mushrooms industry in China: past, present and future. International Journal of Medicinal Mushroom. 8: 1-17.

DOI: 10.1615/IntJMedMushr.v8.i1.10

Chang, S.T. and Miles, P.G. (1988). Edible Mushroom and their cultivation. CRC Press, Inc. Boca Raton, Florida U.S.A. pp. 27, 83, 88.

https://www.cabdirect.org/cabdirect/abstract/19900395757

Dey, R.C. (2006). Mycelial Growth and Oyster Mushroom Production with Different Hormone and Media Composition. M. S. Thesis, Department of Biotechnology, BAU, Mymensingh.

Dhoke, P.K., Chavan, R.A. and Jadhay, V.T. (2001). Cropping period and yield of Oyster mushroom (Pleurotus sajor-caju) on different agro-substrate. Madras Agricultural. Journal. 88 (4-6): 327-329.

Domndon, D. and Poppe, L. (2000). Prevention of yield loss as influenced byTrichoderma in mushroom cultivation. Proceedings, 52nd International Symposium on Crop Protection; Gent, Belgium, 9 May, 2000, Part II. Mededelingen-F aculteit- Landbouwkundige-en- T oegepasteBiologische-Wetenschappen,-Universiteit-Gent. 65 (2): 771-781.

http://hdl.handle.net/1854/LU-133124

Gomez, K.A. and Gomez, A.A. (1984). Statistical procedures for agricultural research. John 
Wiley \& Sons, Inc. New York. http://pdf.usaid.gov/pdf_docs/PNAAR208.pdf

Gupta, J.H. (1989). Yield potentiality of oyster mushroom on wheat straw under natural room temperatures, during March-April and September-October at Saharanpur. Progressive Horticulture. 21(1-2): 184. https://geoscience.net/research/002/279/002279767.php

Habib, M.A. (2005). Comperative study on cultivation and yield Performance of Oyster Mushroom (Pleurotus ostreatus) on different substrates. M. S. Thesis, Department of Biotechnology, BAU,Mymensingh.

Hoa, H. T., Wang, C.L., \& Wang, C.H. (2015). The Effects of Different Substrates on the Growth, Yield, and Nutritional Composition of Two Oyster Mushrooms (Pleurotus ostreatus and Pleurotus cystidiosus). Mycobiology, 43 (4), 423-434.

http://doi.org/10.5941/MYCO.2015.43.4.423

Holman, R.I. (1976). Significance of essential fatty acids in human nutrition, in Lipids, Vol. 1. Paoletti, R., Poscellati, G.and Jasina, G., Eds, Raven press, New York. p. 215.

https://link.springer.com/chapter/10.1007\%2F978-1-4684-3276-3_48

Jafarpour, M., Jalali Z.A., Dehdashtizadeh B., Eghbalsaled S.H. (2010) Evaluation of agricultural wastes and food components usage on growth characteristics of Pleiorotus ostratus musroom on different lignocellulosic by-products. Journal of Industrial Microbiology and Biotechnology. 30: 146-149.

http://citeseerx.ist.psu.edu/viewdoc/download?doi=10.1.1.880.3528\&rep=rep1\&type=pdf

Jhune, C., You, C., Cha, D. and Kim, G. (1990). Effects of thiabendazole on green mold, Trichoderma spp. during cultivation of oyster mushroom, Korean Journal of Mycology.18 (2): 89-95.

http://ocean.kisti.re.kr/downfile/volume/mycology/GNHHDL/1990/v18n2/GNHHDL_1990_ v18n2_89.pdf

Kalita, M.K., Rathaiah, Y. and Bhagabati, K.N. (1997). Effects of some agro-wastes as substrate for Oyster mushroom (Pleurotus sajor-caju) cultivation in Assam. Indian Journal of Hill Farming. 10 (1-2): 109-110.

Khaliq, N., Khan, N.A., Javed, N., and Gondal, A.S. (2013) Production efficiency of Pleiorotus ostratus using celluloic agro-waste. eScience Journal of Plant Pathology. 45(3):12-25. https://escijournals.net/index.php/phytopath/article/download/53/113

Khan, N.A. (2010). Studies on cultivation of Oyster mushroom on commonly available agricultural wastes in Pleurotus. Ph. D Thesis, Dept. of Plant Pathology. University of . Agriculture, Faisalabad.

Khan, S. M., Kausar, A.G. and Ali, M.A. (1981). Yield performance of different strains of oyster mushroom (Pleurotus spp.) on paddy straw in Pakistan. Mushroom Science X1 Sydney. 1: 675-67. agris.fao.org/agris-search/search.do?recordID=US201302036396

Mushroom Growers Handbook 1: Oyster musroom (2004). Available at "www.MushWorld.com" 
Namdev, J.K., Thakur, M.P. and Tripathi, P.N. (2006). Effect of different straw substrates on spawn growth and yield of oyster mushroom (Pleurotus flabellatus). Flora and Fauna Jhansi. 12 (2): 210-212.

Obodai, M., Okine, C. and Vowotor, K.A. (2003). Comparative study on the growth and yield of Pleurotus ostreatus mushroom on different lignocellulosic by-products. Journal of Industrial Microbiology and Biotechnology. 30 (3): 146-149.

https://doi.org/10.1007/s10295-002-0021-1

Rab, S. (1999). Studies on different methods of sterilization on production of Pleurotus sajor-caju. Egyptian Journal of Horticulture. 27 (3): 363-372.

https://www.cabdirect.org/cabdirect/abstract/20013025630

Rai, R.D. and Vijay, B. (1992). Effect of carbendazim on mycelial growth and extracellular enzymes of Pleurotus sajor-caju and Trichoderma viride.Indian Phytopathology. 45 (2): 207-212. https://geoscience.net/research/002/353/002353915.php

Royes, D.J., Rhodes, T.W., Ohga, S. and Sanchez, J.E. (2004). Yield, mushroom size and time to production of Pleurotus cornucopiae (oyster mushroom) grown on switch grass substrate spawned and complemented at various rates. Bioresource Technology. 91: 85-91.

https://doi.org/10.1016/S0960-8524(03)00151-2

Royse, D.J., Fales, S.L. and Karunanandaa, K. (1991). Influence of formaldehyde treated soybean and commercial nutrient supplementation on mushroom (Pleurotus sajor-caju) yield and in-vitro dry matter digestibility of spent substrate. Applied Microbiology and Biotechnology. 36 (3): 425-429. https://link.springer.com/article/10.1007/BF00208169

Sarker, N.C., Hossain, M.M., Sultana, N., Mian, I.H., Karim, A.J.M.S. and Amin, S.M.R. (2007a). Performance of Different Substrates on the growth and Yield of Pleurotus ostreatus (Jacquin ex Fr.) Kummer. Bangladesh Journal of Mushroom.1 (2): 44-49.

Sarker, N.C., Hossain, M.M., Sultana, N., Mian, I.H., Karim, A.J.M.S. and Amin, S.M.R. (2007b). Impact of different Substrates on Nutrient Content of Pleurotus ostreatus (Jacquin ex Fr.) Kummer. Bangladesh Journal of Mushroom. 1(2): 35-38.

Shukla, C. and Biswas, M. (2000). Evaluation of different techniques for oyster mushroom cultivation. Journal of Mycology and Plant Pathology. 30 (3): 431-432.

https://www.cabdirect.org/cabdirect/abstract/20013106689

Stamets, P. (2000) Growing gourmet and medicinal mushrooms; $3^{\text {rd }}$ Edtn. Ten Speed Press. Berkley-Toronto. pp. 153-167.

Straatsma, G., Gerrits, P.G., Thissen, T.N.M., Amsing, G.M., Loeffen, H. and Griensven, J. L. D. V. (2000). Adjustment of the composting process for mushroom cultivation based on initial substrate composition. Bioresource Technology. 72: 67-74.

https://doi.org/10.1016/S0960-8524(99)00088-7

Subramanian, T.R. (1986). Nutritive Value. Mushroom Extension Bulletin. Indian Institute of Horticulture. 


\section{Macrothink}

Journal of Agricultural Studies

ISSN 2166-0379 2018, Vol. 6, No. 1

Suzuki, S. and Oshima, S. (1979). Influence of Shiitake (Lentenus edodes) on human serum cholesterol.

Tewari, R. P. (1986). Mushroom cultivation. Extension Bulletin. Indian Institute of Horticulture research, India. pp. 8: 36.

World Bank. (2004). World Development Reports. Oxford University Press, Inc., New York.

Yoshida, N., Takahashi, T., Nagao, T. and Chen, J. (1993). Effect of edible mushroom (Pleurotus ostreatus) cultivation on in vitro digestibility of wheat straw and sawdust substrate. Journal of Japanese Society of Grassland Science. 39 (2): 177-182.

https://geoscience.net/research/002/812/002812333.php

\section{Copyright Disclaimer}

Copyright for this article is retained by the author(s), with first publication rights granted to the journal.

This is an open-access article distributed under the terms and conditions of the Creative Commons Attribution license (http://creativecommons.org/licenses/by/4.0/). 